\title{
Antibiotic Resistance of Enterococcus faecalis from Persistent Endodontic Infections
}

\author{
Resistencia Antibiótica de Enterococcus faecalis \\ Provenientes de Infecciones Endodónticas Persistentes
}

\author{
Natalia Seguel'; Mario Quezada-Aguiluz',4; Gerardo González-Rocha',4; \\ Helia Bello-Toledo ${ }^{2,4}$ \& Gabriela Sánchez-Sanhueza ${ }^{2,3}$
}

SEGUEL, N.; QUEZADA-AGUILUZ, M.; GONZÁLEZ-ROCHA, G.; BELLO-TOLEDO, H. \& SÁNCHEZ-SANHUEZA, G. Antibiotic resistance of Enterococcus faecalis from persistent endodontic infections. Int. J. Odontostomat., 13(3):448-456, 2020.

\begin{abstract}
Enterococci are important nosocomial pathogens due to their intrinsic multiresistance and the acquisition of new antibiotic resistance genes (ARG). Enterococcus faecalis has been shown to be one of the main pathogens in persistent endodontic infections, therefore, the main objective of this study was to evaluate the phenotype and resistance genotype of strains of $E$. faecalis isolated from teeth with persistent endodontic lesions, to the most commonly prescribed antibiotics in dentistry. Thirteen strains of $E$. faecalis of different pulsotype were analyzed to evaluate the susceptibility to antibiotics, amoxicillin, amoxicillin/clavulanic acid, tetracycline, erythromycin and metronidazole, using the Epsilometer test (E- test) and the presence of beta-lactamases with nitrocefin test. Finally, the detection of ARG was performed with a molecular polymerase chain reaction (PCR) technique and confirmed by the sequencing of the amplification products. Fisher's exact test was used, using $95 \%$ confidence. Regarding the phenotype of resistance, the evaluated strains, independent of the pulsotype, were totally resistant to the action of metronidazole. Antibiotics with higher minimum inhibitory concentration (MIC) after metronidazole include tetracycline and erythromycin. In contrast, lower MIC are applied to the combination of amoxicillin with clavulanic acid. The nitrocefin test was positive only in one strain. Genotypically, two genetically distant strains isolated from a single patient, presented a genotype of resistance to erythromycin, determined by the presence of the ermB gene. No statistically significant relationship was found between phenotypic resistance and the presence of ARG in relation to erythromycin ( $p>0.05)$. It was concluded that isolates of $E$. faecalis from persistent endodontic infections showed phenotypes of resistance to several antimicrobial agents, all of which were susceptible to amoxicillin/clavulanic acid. Periodic evaluation of susceptibility to antibiotics is suggested as an important practice for the surveillance of antibiotic resistance in oral strains.
\end{abstract}

KEY WORDS: E. faecalis, antibiotic resistance, persistent endodontic lesions, antibiotic resistance genes.

\section{INTRODUCTION}

Enterococcus faecalis (E. faecalis) is a bacterial species involved in post-treatment of apical periodontitis due to its capacity to persist after chemical-mechanical treatments during the disinfection process of the root canals. The presence of virulence factors and ARG expression may would produce the failure of conventional endodontic treatments (Duggan \& Sedgley, 2007). The overmedication or inadequate use (use when the etiology is not infectious) of antibiotics have been the key to put a selective pressure in these bacteria and that could be playing a role in persistent endodontic pathologies, through resistance mechanisms encoded in their genome. Some species of the oral cavity can carry, in addition to ARG, genes that encode virulence factors, which facilitate their persistence and survival

\footnotetext{
${ }^{1}$ Postgrade Student, Faculty of Dentistry, University of Concepción, Chile.

${ }^{2}$ Laboratorio de Investigación en Agentes Antibacterianos (LIAA), Facultad de Ciencias Biológicas, Universidad de Concepción. Departamento de Microbiología, Concepción, Chile.

${ }^{3}$ Department of Restorative Dentistry, Faculty of Dentistry, University of Concepción. Concepción, Chile.

${ }^{4}$ Millennium Nucleus on Interdisciplinary Approach to Antimicrobial Resistance, Chile (MICROB-R).
} 
in this complex environment (Stuart et al., 2006; Prazmo et al., 2016). Furthermore, processes of horizontal gene transfer between communities organized in biofilms play an important role in the exchange of genetic information that gives them new traits that allow them to survive (Davies \& Davies, 2010).

Apical periodontitis is an inflammatory reaction of the periradicular tissues caused by a microbial infection in the root canals of the teeth (Nair, 2004). In cases of patients with risk of developing bacterial endocarditis, systemic antibiotics become an important complement to the endodontic treatment used as prophylaxis (Anderson et al., 2018). The treatment of acute oral infections is mainly empirical, using different families of antibiotics, among which are beta-lactams, lincosamides, nitroimidazoles, tetracyclines, etc. Beta-lactams (mainly amoxicillin) are used as first-line treatment for oral cavity infections (Oberoi et al., 2015). Bacterial cultures and molecular studies have confirmed that $E$. faecalis is one of the frequent bacteria isolated from the root canal system after endodontic treatment (Pinheiro et al., 2003; Anderson et al.). Enterococcus spp. have acquired genes that confer resistance to several classes of antibiotics, including clindamycin, erythromycin, tetracycline, chloramphenicol and, more recently, vancomycin (Gomes et al., 2011; Medeiros et al., 2014; Barbosa-Ribeiro et al., 2016; Anderson et al.). Although the incidence of resistant strains is more frequent in hospital or systemic infections, studies with bacteria isolated from endodontic infections have shown the emergence of bacterial resistance (Gomes et al.), but there are no reports yet in Chilean population. It has been shown that the frequency of $E$. faecalis found in persistent periradicular lesions is higher. In fact, failed cases of root canal treatment are nine fold more likely to contain $E$. faecalis than primary endodontic infections (Barbosa-Ribeiro et al.), and studies on teeth with periradicular lesions have shown a prevalence ranging between 24 and $77 \%$ (Stuart et al.) depending on the methodology used.

E. faecalis has several strategies to evade the action of antimicrobials and the immune system. It has various virulence factors including lytic enzymes, aggregation substance, and lipoteichoic acid. E. faecalis is able to suppress the action of lymphocytes, potentially contributing to endodontic failure (Prazmo et al.). It is small enough to colonize and live properly inside the dentinal tubules (Sun \& Song, 2011; Sun et al., 2012). It has the capacity to withstand prolonged periods of starvation until adequate nutritional supply is available, and to survive in contact with intracanal calcium hydroxide medications for more than 10 days (Rams et al., 2013). E. faecalis is able to form a biofilm that helps to resist adverse conditions (Stuart et al.; Zhu et al., 2010; Preethee et al., 2012). However, there is limited information about the presence of ARG in strains from endodontic failures and its relationship with the resistance phenotype. The aim of this study was to evaluate the resistant phenotype and resistant genotype of genetically non-related strains of $E$. faecalis isolated from teeth with persistent endodontic lesions.

\section{MATERIAL AND METHOD}

Bacterial strains. Thirteen clinical isolates of $E$. faecalis obtained from patients with dental pieces previously treated with indication of endodontic retreatment and with diagnosis of apical periodontitis were included. These strains were isolated from patients treated at the clinic of the Specialty of Endodontics of the Universidad de Concepción, Chile (Sánchez-Sanhueza et al., 2015). The study was carried out in compliance with the protocol approved by the Faculty's Ethical Committee (number C.I.Y.B 08/ 14). Each strain corresponds to a distinct pulsotype (PFGE patterns) that was previously determined (Sánchez-Sanhueza et al., 2018).

Antibiotic resistance phenotype: The minimum inhibitory concentration (MIC) for each antibiotic was determined by Epsilometer test (Etest $₫$, BioMérieux, Marcy-l'Etoile, France). Each strain was inoculated with a standardized inoculum of $1,5 \times 10^{8} \mathrm{CFU} / \mathrm{mL}$ on Mueller Hinton agar plates and cultured for $24 \mathrm{~h}$ at $37^{\circ} \mathrm{C}$ in aerobic conditions. Strips impregned with amoxicillin, amoxicillin/clavulanic acid, tetracycline, and erythromycin were used. In the case of metronidazole, the test was carried under anaerobic conditions. The breakpoints to determine susceptibility or resistance were those recommended by CLSI (M100-S27, 2019). Phenotypic detection of beta-lactamase was carried out by the cefinase test (bioMérieux, Marcy-l'Etoile, France). In a sterile Petri dish, the disks were placed, moistened with sterile distilled water, and a one colony was deposited on the disk surface, leaving them at room temperature by 60 minutes. The change of the disk color to red indicates the production of a betalactamases (Lopardo \& Blanco, 2007). The strains Staphylococcus aureus ATCC 43300 was a positive control, because it produces a beta-lactamase. 
DNA Extraction: 4-5 colonies of each strain were resuspended in $200 \mathrm{ml}$ of $5 \%$ Chelex ${ }^{\circledR}$ (Bio-Rad, USA) supplemented with $2.5 \mathrm{ml}$ of proteinase $\mathrm{K}(20$ $\mathrm{mg} / \mathrm{ml}$ ) (Thermo Scientific, Massachusetts, USA). It was mixed and incubated at $56{ }^{\circ} \mathrm{C}$ for $45 \mathrm{~min}$, homogenized again and boiled for $8 \mathrm{~min}$. Next, it was centrifuged at $14,000 \mathrm{rpm}$ for $1 \mathrm{~min}$. The DNA extracted (template) obtained was stored at $4{ }^{\circ} \mathrm{C}$ for later use.

Polymerase chain reaction (PCR): The extracted DNA was diluted with sterile distilled water in a ratio 1:4 $(25 \mu \mathrm{L} / 75 \mu \mathrm{L})$. For the conventional PCR reaction, the KAPA Taq ReadyMix Polymerase kit (KAPA Biosystems, Massachusetts, USA) was used in the following amounts: KAPA Taq $5 \mu \mathrm{L}$, Water $3.8 \mu \mathrm{L}$, primer forward $0.1 \mu \mathrm{L}$, primer reverse $0.1 \mu \mathrm{L}$, DNA template $1 \mu \mathrm{L}$. The nucleotide sequences of the primers used are shown in Table I. Amplification was performed in a Veriti 96-well thermal cycler (Applied Biosystems, Foster City, CA, USA) with the programs described in Table II. The amplification products (amplicons) were separated by agarose gel electrophoresis (1.5\%), to which the SafeViewTM reagent $(0.5 \mu \mathrm{g} / \mu \mathrm{L})$ was added and visualized in a UV transilluminator (Uvitec UVIdoc HD2 Documentation System from Gels, Warwickshire, UK). Finally, the presence of ARG was corroborated by sequencing the amplicons (Macrogen, Seoul, Korea).

Statistical analysis: The data was processed with the statistical software IBM SPSS Statistics v.25.0 where parameters of descriptive statistics such as frequency and percentage were used for the analysis and presentation of the results. To analyze a possible relationship between the resistance / susceptibility phenotype and the presence of ARG of each strain, Fisher's exact test was used, using $95 \%$ confidence.

Table I. List of primers.

\begin{tabular}{|c|c|c|c|c|c|}
\hline Genes & Resistance to & $5^{\prime} \rightarrow$ 3' nucleotide sequence & $\begin{array}{l}\text { Amplicon } \\
\text { size (bp) }\end{array}$ & $\operatorname{Tm}\left(\mathrm{C}^{\circ}\right)$ & Reference \\
\hline erm(a) & erythromycin & $\begin{array}{l}\text { F: TCTAAAAAGCATGTAAAAGAA } \\
\text { R: CTTCGATAGTTTATTAATATTAGT }\end{array}$ & 645 & 50 & (Lins, 2013) \\
\hline erm(b) & erythromycin & $\begin{array}{l}\text { F: GAAAAGGTACTCAACCAAATA } \\
\text { R: AGTAACGGTACTTAAATTGTTTC }\end{array}$ & 639 & 52 & (Lins, 2013) \\
\hline $\operatorname{tet}(W)$ & tetracycline & $\begin{array}{l}\text { F: GAGAGCCTGCTATATGCCAGC } \\
\text { R: GGGCGTATCCACAATGTTAAC }\end{array}$ & 168 & 64 & $\begin{array}{l}\text { (Jungermann, } \\
\text { 2011) }\end{array}$ \\
\hline $\operatorname{tet}(Q)$ & tetracycline & $\begin{array}{l}\text { F: TTATACTTCCTCCGGCATCG } \\
\text { R: ATCGGTTCGAGAATGTCCAC }\end{array}$ & 904 & 55 & $\begin{array}{l}\text { (Jungermann, } \\
\text { 2011) }\end{array}$ \\
\hline bla $_{T E M-1}$ & $\beta$-lactams & $\begin{array}{l}\text { F: CCAATGCTTAATCAGTGAGG } \\
\text { R: ATGAGTATTCAACATTTCCG }\end{array}$ & 858 & 55 & $\begin{array}{l}\text { (Jungermann, } \\
\text { 2011) }\end{array}$ \\
\hline blaZ & $\beta$-lactams & $\begin{array}{l}\text { F: CAGTTCACATGCCAAAGAG } \\
\text { R: TACACTCTTGGCGGTTTC }\end{array}$ & 846 & 54 & (Lins, 2013) \\
\hline$c f x A$ & $\beta$-lactams & $\begin{array}{l}\text { F: GCAAGTGCAGTTTAAGATT } \\
\text { R: GCTTTAGTTTGCATTTTCATC }\end{array}$ & 802 & 58 & (Lins, 2013) \\
\hline nim & metronidazole & $\begin{array}{l}\text { F: ATGTTCAGAGAAATGCGGCGTAAGCG } \\
\text { R: GCTTCCTTGCCTGTCATGTGCTC }\end{array}$ & 458 & 62 & (Koukos, 2016) \\
\hline
\end{tabular}

F: forward; R: reverse

Table II. PCR Programs.

\begin{tabular}{|c|c|c|c|c|c|c|c|}
\hline \multirow[t]{2}{*}{ Gen } & \multirow{2}{*}{$\begin{array}{c}\text { Initial } \\
\text { denaturation }\end{array}$} & \multicolumn{4}{|c|}{ Amplification } & \multirow{2}{*}{$\begin{array}{c}\text { Final } \\
\text { Extension }\end{array}$} & \multirow[t]{2}{*}{ Ref } \\
\hline & & $\mathrm{n}^{\circ}$ Cycles & Denaturation & Alignment & Extension & & \\
\hline erm(a) & $95^{\circ} \mathrm{C}-1 \mathrm{~min}$ & 26 & $94^{\circ} \mathrm{C}-45 \mathrm{~s}$ & $50^{\circ} \mathrm{C}-45 \mathrm{~s}$ & $72^{\circ} \mathrm{C}-90 \mathrm{~s}$ & $72^{\circ} \mathrm{C}-15 \mathrm{~min}$ & (Lins et al., 2013) \\
\hline erm(b) & $95^{\circ} \mathrm{C}-1 \mathrm{~min}$ & 26 & $94^{\circ} \mathrm{C}-45 \mathrm{~s}$ & $50^{\circ} \mathrm{C}-45 \mathrm{~s}$ & $72^{\circ} \mathrm{C}-90 \mathrm{~s}$ & $72^{\circ} \mathrm{C}-15 \mathrm{~min}$ & (Lins et al., 2013) \\
\hline $\operatorname{tet}(W)$ & $94^{\circ} \mathrm{C}-5 \mathrm{~min}$ & 30 & $94^{\circ} \mathrm{C}-30 \mathrm{~s}$ & $64^{\circ} \mathrm{C}-30 \mathrm{~s}$ & $72^{\circ} \mathrm{C}-30 \mathrm{~s}$ & $72^{\circ} \mathrm{C}-7 \mathrm{~min}$ & (Aminov et al., 2001) \\
\hline $\operatorname{tet}(Q)$ & $94^{\circ} \mathrm{C}-5 \mathrm{~min}$ & 35 & $94^{\circ} \mathrm{C}-60 \mathrm{~s}$ & $55^{\circ} \mathrm{C}-60 \mathrm{~s}$ & $72^{\circ} \mathrm{C}-60 \mathrm{~s}$ & $72^{\circ} \mathrm{C}-10 \mathrm{~min}$ & (Ng et al., 2001) \\
\hline bla $_{\text {tem-1 }}$ & $95^{\circ} \mathrm{C}-2 \min$ & 30 & $96^{\circ} \mathrm{C}-30 \mathrm{~s}$ & $60^{\circ} \mathrm{C}-30 \mathrm{~s}$ & $72^{\circ} \mathrm{C}-30 \mathrm{~s}$ & $72^{\circ} \mathrm{C}-10 \mathrm{~min}$ & (Chouchani et al., 2012) \\
\hline blaz & $95^{\circ} \mathrm{C}-10 \mathrm{~min}$ & 50 & $94^{\circ} \mathrm{C}-12 \mathrm{~s}$ & $55^{\circ} \mathrm{C}-15 \mathrm{~s}$ & $72^{\circ} \mathrm{C}-20 \mathrm{~s}$ & $72^{\circ} \mathrm{C}-10 \mathrm{~min}$ & (Pereira et al., 2014) \\
\hline cfxA & $94^{\circ} \mathrm{C}-5 \mathrm{~min}$ & 25 & $94^{\circ} \mathrm{C}-60 \mathrm{~s}$ & $58^{\circ} \mathrm{C}-60 \mathrm{~s}$ & $72^{\circ} \mathrm{C}-90 \mathrm{~s}$ & $72^{\circ} \mathrm{C}-10 \mathrm{~min}$ & (Fosse et al., 2002) \\
\hline nim & $94^{\circ} \mathrm{C}-10 \mathrm{~min}$ & 32 & $94^{\circ} \mathrm{C}-30 \mathrm{~s}$ & $62^{\circ} \mathrm{C}-60 \mathrm{~s}$ & $72^{\circ} \mathrm{C}-60 \mathrm{~s}$ & $72^{\circ} \mathrm{C}-10 \mathrm{~min}$ & (Koukos et al., 2016) \\
\hline
\end{tabular}




\section{RESULTS}

The results obtained in the E-test, summarized in Table III, show that all strains were susceptible to amoxicillin (MIC, $6-0.38 \mu \mathrm{g} / \mathrm{mL}$ ) and to the amoxicillin/clavulanic acid combination (MIC, $6-0.025 \mu \mathrm{g} / \mathrm{mL}$ ), but resistant to metronidazole (MIC $>256 \mu \mathrm{g} / \mathrm{mL}$ ). The higher MIC were observed in metronidazole, tetracycline and erythromycin. Three strains (3.3; 6.5 and 9.2) were resistant to these latest antibiotics simultaneously, and belongs to three different PFGE pulsotypes. However, it should be noted that strains 3.1 and $3.3(90.3 \%$ similarity), as well as 10.3 and 9.2 (94.5\% similarity), despite being considered closely related, exhibited a completely different resistant phenotype, except for strains 4.3 and $7.3(96.8$ $\%$ similarity), which only had in common that they were resistant to metronidazole. The detection of beta-lactamases was performed by the nitrocefin test, where only the strain 9.1 showed the production of beta-lactamases.

Molecular analysis with PCR only evidenced the presence of two ermB genes for strains 6.4 and 6.5 (Fig. 1). Sequencing of both ermB genes was performed, which was over 600 base pairs (bp). A good quality of the signal was obtained, observing separated peaks, with the
G signal above 500 as observed in Figure 2. Both genes showed a similarity of $99 \%$ identity with the reference in Gene Bank (ID: AP018546. 1), using the BLASTN® computer tool ("Gene Bank," 2019), which shows that the gene is located in the plasmid pKUB3007-3 KUB3007 (Kuroda et al., 2018). The results indicate that there is no statistically significant relationship between the presence of the gene and the antibiotic resistance to erythromycin $(p=0.077)$.

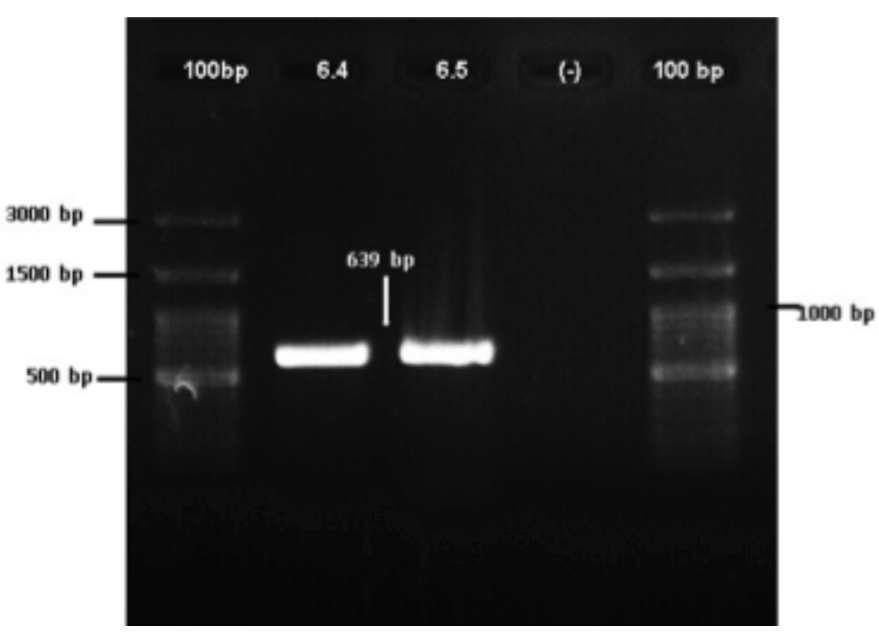

Fig. 1. PCR identification of the ermB gene for strains 6.4 and 6.5 .

Table III. E-test based antibiotic resistance profiles.

\begin{tabular}{ccccccc}
\hline \multirow{2}{*}{ Strain } & $\begin{array}{c}\text { PFGE } \\
\text { pulsotype }\end{array}$ & AMX & AMC & $\begin{array}{c}\text { Antimicrobials } \\
\text { TET }\end{array}$ & ERY & MTZ \\
\hline 3.1 & K1 & 2 & 1.5 & 1.5 & 0.5 & $>256$ \\
3.3 & K2 & 6 & 6 & 128 & 192 & $>256$ \\
4.3 & $\mathrm{I} 1$ & 2 & 2 & 6 & 6 & $>256$ \\
6.4 & $\mathrm{M} 1$ & 0.75 & 0.75 & 4 & $>256$ & $>256$ \\
6.5 & $\mathrm{~L} 1$ & 0.5 & 0.38 & 64 & $>256$ & $>256$ \\
7.3 & $\mathrm{I} 2$ & 1.5 & 1 & 4 & 4 & $>256$ \\
8.6 & $\mathrm{M} 2$ & 0.75 & 0.75 & 1 & 0.75 & $>256$ \\
9.1 & $\mathrm{C} 1$ & 0.025 & 0.75 & 0.25 & $>256$ \\
9.2 & $\mathrm{~A} 1$ & 2 & 0.75 & 24 & $>256$ & $>256$ \\
10.3 & $\mathrm{~A} 2$ & 0.75 & 0.5 & 0.75 & 1 & $>256$ \\
12.4 & $\mathrm{H} 1$ & 0.75 & 0.5 & 1.4 & $>256$ \\
15.3 & $\mathrm{~F} 1$ & 0.38 & 0.38 & 6 & 2 & $>256$ \\
16.3 & L2 & 13 & 13 & 7 & 0.064 & $>256$ \\
\hline & Resistant strains & $0 \%$ & $0 \%$ & $46.15 \%$ & $30.77 \%$ & $100 \%$ \\
\hline
\end{tabular}

AMX: amoxicillin, AMC: amoxicillin + ac. Clavulanic, ERY: erythromycin, TET: tetracycline, MTZ: metronidazole. N: resistant strains. * Interpretation based on the cut-off points established by the CLSI 2017 
SEGUEL, N.; QUEZADA-AGUILUZ, M.; GONZÁLEZ-ROCHA, G.; BELLO-TOLEDO, H. \& SÁNCHEZ-SANHUEZA, G. Antibiotic resistance of Enterococcus faecalis from persistent endodontic infections. Int. J. Odontostomat., 13(3):448-456, 2020.

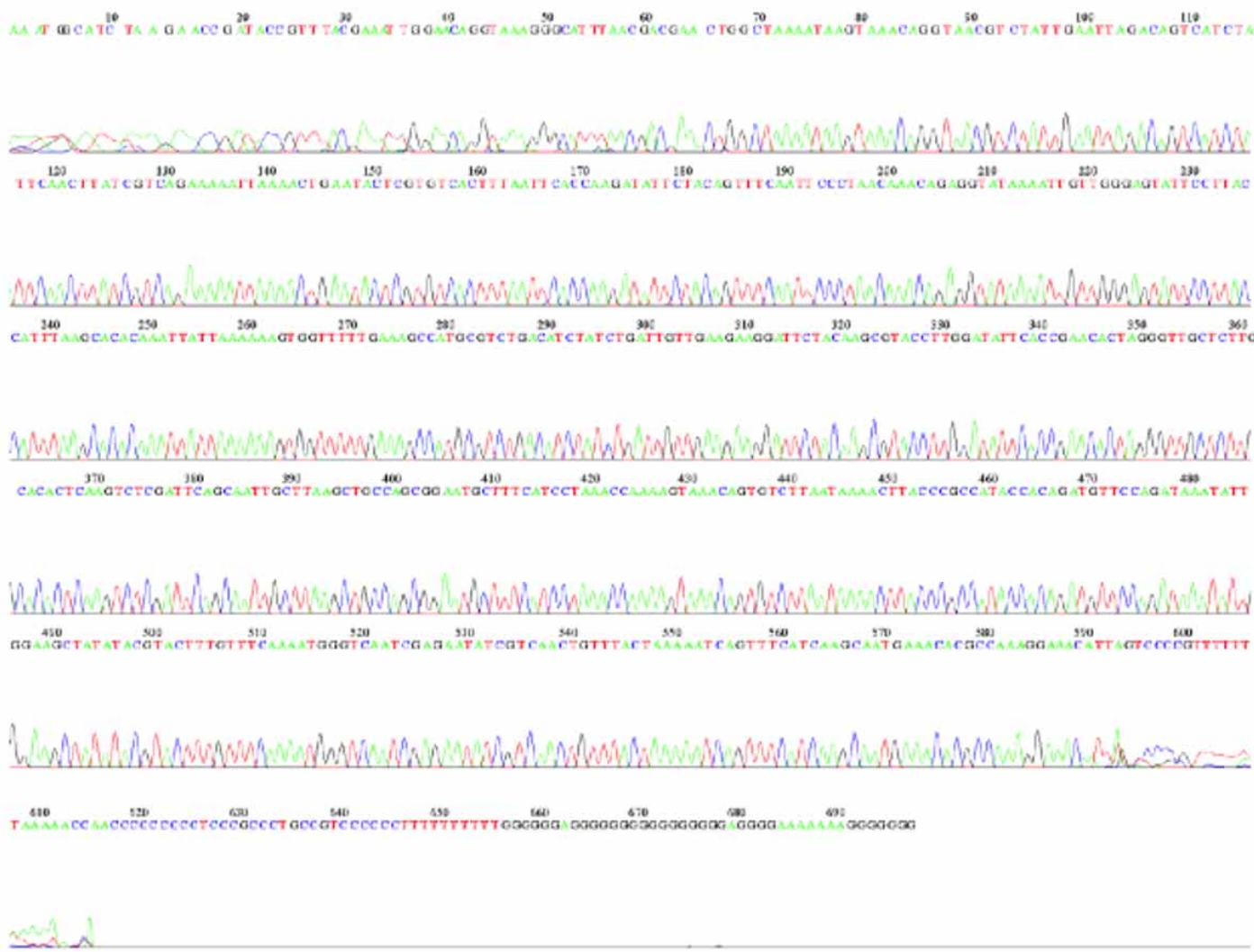

Fig. 2. Sequencing chromatogram of the ermB gene forward for strain 6.4. (File: 6-4_ermB_F.ab1 Run Ended: 2018/11/26 20:7:28 Signal G:4306 A:8983 C:10134 T:11462 Sample: 6-4_ermB_F Lane: 6 Base spacing: 15.834887698 bases in 28993 scans)

\section{DISCUSSION}

$E$. faecalis is one of the main species resistant to treatments in endodontic infections (Jungermann et al., 2011) and this was the main reason to include these clinical strains into the study. On the other hand, the inclusion criterion for the antibiotics used in this study was the regularity in which they are used in the dental clinic and are those suggested by the European and American Endodontic Societies (AAE, 2017; SeguraEgea et al., 2018). The European Society of Endodontics (Segura-Egea et al.), taking into account the problem of antibiotic resistance, provides recommendations for protocols for the use of systemic antibiotics in endodontics, where beta-lactam antibiotics (penicillin $\mathrm{V}$ and amoxicillin) are the first line treatment. Following the rules, an endodontic infection must be compromising a patient's overall fitness to justify the need for antibiotics (ie, fever, swelling, lymphadenopathy, trismus or general malaise) (Rodriguez-Núñez et al., 2009). It is stipulated that the vast majority of pathologies of endodontic origin does not justify the use of systemic antibiotic therapies (Bolfoni et al., 2018). In the rest of the pathologies, the use of antibiotics in lower effective therapeutic doses and reduced periods of time in comparison with other systemic infections, is recommended (Segura-Egea et al.). In the present study, the patients from whom the isolates of $E$. faecalis were obtained fulfilled the inclusion criteria of not having used antibiotic therapy in the 3 months prior to taking the sample. However, this does not ensure that these have not been exposed to antibiotic therapy previously and the number of exposures, with the consequent selection of resistant bacteria.

Beta-lactamase-producing bacteria are more frequently isolated in odontogenic infections of patients who have previously received these treatments, and the longer the duration, the greater the number of resistant bacterial strains isolated (Poveda Roda et al., 2007). In the present study there is no information on 
whether patients were exposed to beta-lactam antibiotics prior to the 3 months requested as inclusion criteria, nor at the time the endodontic treatment failed was performed. Amoxicillin/clavulanic acid combination and amoxicillin were the antibiotics that exhibited the lowest MIC, in agreement with other studies in the literature, which indicate that penicillins are the firstchoice treatment for oral pathologies (Barbosa-Ribeiro et al.; Komiyama et al., 2016). However, the presence of penicillin-resistant enterococcus strains has been reported in endodontic infections (Koukos et al., 2016), which underscores the need for periodic susceptibility testing of these isolates. TEM-type beta-lactamases have been found in a wide variety of bacteria, generally Gram positive (Rôças \& Siqueira, 2012). In the literature, unlike our study, some authors have found the presence of the bla $a_{T E M}$ gene in strains of $E$. faecalis isolated from endodontic pathology (Jungermann et al.; Rôças \& Siqueira, 2013) and in particular one of them that reported in $30 \%$ of the samples (Anderson et al., 2018). However, emphasize that enterococci are not often producers of beta-lactamase (Fontana et al., 1992), which could be related to the high susceptibility to amoxicillin in this study. Strain 9.1 showed evidence of beta-lactamase the nitrocefin test; however, when the same strain was assayed with the E-test, it was totally susceptible to amoxicillin and amoxicillin/ clavulanic acid. This may be due to a low betalactamase activity and the MIC value is less than necessary to generate resistance. It has also been described that the nitrocefin test can generate false positives or negatives because many times the molecular reactions are incomplete (Pitkälä et al., 2007), although an effectiveness greater than $90 \%$ has been described (Vergis et al., 2018). It would be interesting to sequence the genome of this strain to identify the beta-lactamase involved.

The clinical importance of tetracyclines in endodontics is their use in various intracanal medications. A study had previously reported the presence of tet $W$ and tet $Q$ genes in endodontic infections (Jungermann et al.); however, the main genes found in strains of tetracycline-resistant enterococci were the tetS and tetM (Roberts et al., 2006; Jungermann et al.). In previous studies have been reported a variable percentage of resistance to tetracycline (between $5 \%$ and $75 \%$ ) (Lins et al., 2013; Rams et al.; Komiyama et al.), which agrees to the phenotypic resistance to tetracycline although no tet genes were found in this study. It is suggested that the search for other tet genes be extended in those strains with a tetracycline resistant phenotype.
In reference to metronidazole, its antibacterial activity preferentially is focused upon anaerobic Grampositive bacilli and Gram-negative cocci, some protozoa and Helicobacter pylori. In the dental field it is used for mainly maxillofacial or periodontal infections, due to the predominance of anaerobic bacteria in this kind of pathology (Poveda Roda et al.). In this case, phenotypic resistance to metronidazole was expected because it has an antimicrobial spectrum limited to strict anaerobic bacteria and protozoa (Rams et al.).

Four isolates were phenotypically resistant to erythromycin, which agrees with previous reports showing different degrees of resistance to this macrolide, so that the percentage obtained in the study around $30 \%$, keeps close relationship with what was found previously (Skucaite et al., 2010; Rams et al.; Komiyama et al.). Two of the isolates were positive for the ermB gene, which is described as one of the most common genes in oral isolates with prevalence in strains highly resistant to erythromycin (Jain et al., 2016). The erm gene confers resistance to the antibiotics macrolide-lincosamide-streptogramin B (MLSB), three groups of antimicrobials of different chemical structures, but with similar mechanisms of action. A methylase encoded by erm results in a specific adenine base dimethylation in the $23 \mathrm{~S}$ subunit of ribosomal RNA which affects the binding of antibiotics to their ribosome site of action (Min et al., 2008). On the other hand, four strains were phenotypically resistant to erythromycin, and only two of them identified the ermB gene. However, the statistical study concludes that there is no relationship between the presence of the gene and antibiotic resistance ( $p>$ 0.05 ), so it could be other genes or resistance mechanisms that were not included in this study.

One of the principal limitations of this study was to demonstrate the location of the ermB and a possible relation with mobile genetic elements. For the case of ermB, it was identified that the gene is located in the plasmid pKUB3007-3 KUB3007 (Kuroda et al.; Yin et al., 2018). The importance of this lies in that being a plasmid a mobile element within the genome of the bacteria could contribute to the processes of horizontal genes transfer with other microorganisms in the community, which could transform the root canal into a reservoir of genes that could help the propagation to other anatomical areas where these drugs are routinely used as treatments (Davies \& Davies).

E. faecalis shows fairly high levels of resistance to many antimicrobial agents, presumably due to the 
presence of efflux pumps (Davis et al., 2001). In the present study it did not include them, so it could be related to phenotypic resistance to antibiotics. The mefA and $m s r A / m s r B$ efflux pumps (Chouchani et al., 2012), associated with the production of beta-lactamase TEM1 , among them resistant to erythromycin and ampicillin (Rôças \& Siqueira, 2012).

Glycopeptides have seen an increase in resistance to last-line antibiotics, such as vancomycin, due to the expression of van-like genes (Miller et al., 2014) To emphasize that, although the present study identified the presence of genes of resistance to erythromycin in 2 strains of $E$. faecalis, this information does not indicate that these bacteria are functionally or phenotypically resistant to antibiotics. The mechanisms of antibiotic resistance are linked to gene regulation, mediating all the functions associated with the evasion of antibiotic action and have described processes of: mutation of the gene, activation of specific regulatory genes and of global transcription (Troncoso et al., 2017). The regulation of gene expression in a cell starts at the level of transcription of DNA into mRNA. The circumstances under which a particular gene is positively- or negatively-regulated provide important clues about the function of genes (Jungermann et al.; Troncoso et al.).

Studies related to antimicrobial susceptibility are based on culture dependent microorganisms. Of the microorganisms of oral microbiota only have this condition less than $1 \%$, so the study is limited (Wade, 2011). Metagenomics is a new field in which you can obtain the genome sequences of the different microorganism communities, extracting and analyzing their DNA globally, without the need to carry out cultures. This is important to study the interaction between the different microorganisms, their organization and the identification of new structures that could be related to the presence of ARG. In this case, the structures that generate the resistance phenotype have been called resistome, composed of the total set of antibiotic resistance factors (ARD) (Sukumar et al., 2016).

Finally, during endodontic treatments the use of rubber dam isolation in the procedure is a basic standard to prevent the entry of microorganisms into the root canal system. There is clear evidence of the effectiveness of endodontic treatment when rubber dam is used (Anabtawi et al., 2013; Goldfein et al.,2013). This study incorporated strains of patients, which in many cases did not use tooth isolation, so it could be a cause of the nosocomial contamination.

\section{CONCLUSION}

Within the limitations of this study, it can be concluded that $E$. faecalis isolates of persistent endodontic infections showed varying degrees of resistance to several antibacterial agents commonly used in dentistry, with beta-lactams showing the lowest MICs, where only a strain showed beta-lactamase action. Two strains not genetically related, evidenced the presence of ermB genes related to the phenotypic resistance to erythromycin. Finally, regarding the relationship between the phenotype/genotype of antibiotic resistance, in this study there was no relationship between both parameters. The periodic evaluation of antibiotic susceptibility is an important practice to establish the best therapy if its use is necessary.

SEGUEL, N.; QUEZADA-AGUILUZ, M.; GONZÁLEZ-ROCHA, G.; BELLO-TOLEDO, H. \& SÁNCHEZ-SANHUEZA, G. Resistencia antibiótica de Enterococcus faecalis provenientes de infecciones endodónticas persistentes. Int. J. Odontostomat., 13(3):448-456, 2020.

RESUMEN: Los enterococos son importantes patógenos nosocomiales debido a su multi resistencia intrínseca y la adquisición de nuevos genes de resistencia a los antibióticos (ARG). Enterococcus faecalis es uno de los principales patógenos en infecciones endodónticas persistentes, por lo tanto, el objetivo principal de este estudio fue evaluar el fenotipo y el genotipo de resistencia de cepas de $E$. faecalis aisladas de dientes con lesiones endodóncicas persistentes, a los antibióticos comúnmente recetados en odontología. Se analizaron 13 cepas de E. faecalis de diferentes pulsotipos para evaluar la susceptibilidad a los antibióticos, amoxicilina, amoxicilina / ácido clavulánico, tetraciclina, eritromicina y metronidazol, utilizando la prueba de Epsilometría (E-test) y la presencia de beta-lactamasas con prueba de nitrocefina. Finalmente, la detección de ARG se realizó con una técnica molecular de reacción en cadena de la polimerasa (PCR) y se confirmó mediante la secuenciación de los productos de amplificación. Se utilizó la prueba exacta de Fisher, con un $95 \%$ de confianza. En cuanto al fenotipo de resistencia, las cepas evaluadas, independientes del pulsotipo, fueron totalmente resistentes a la acción del metronidazol. Los antibióticos con los valores más altos de concentración mínima inibitoria (CMI) después del metronidazol incluyen tetraciclina y eritromicina. En contraste, las CMI mas bajas se aplican a la combinación de amoxicilina con ácido clavulánico. La prueba de nitrocefina fue positiva solo en una cepa. Genotípicamente, dos cepas distantes genéticamente, aisladas de un mismo paciente fueron positivas para el gen ermB. No se encontró una relación estadísticamente significativa entre la resistencia fenotípica 
y la presencia de $A R G$ en relación con la eritromicina $(p>$ $0,05)$. Se concluyó que los aislamientos de E. faecalis de infecciones endodónticas persistentes mostraron fenotipos de resistencia a varios agentes antimicrobianos, todos los cuales fueron susceptibles a amoxicilina / ácido clavulánico. Se sugiere una evaluación periódica de la susceptibilidad a los antibióticos como una práctica importante para la vigilancia de la resistencia a los antibióticos en las cepas orales.

PALABRAS CLAVE: E. faecalis, resistencia a antibióticos, lesiones endodóncicas persistentes, genes de resistencia a antibióticos.

\section{REFERENCES}

AAE Position Statement: AAE Guidance on the Use of Systemic Antibiotics in Endodontics. J. Endod., 43(9):1409-13, 2017.

Aminov, R. I.; Garrigues-Jeanjean, N. \& Mackie, R. I. Molecular ecology of tetracycline resistance: development and validation of primers for detection of tetracycline resistance genes encoding ribosomal protection proteins. Appl. Environ. Microbiol., 67(1):2232, 2001.

Anabtawi, M. F.; Gilbert, G. H.; Bauer, M. R.; Reams, G.; Makhija, S. K.; Benjamin, P. L.; Dale Williams, O. \& National Dental PracticeBased Research Network Collaborative Group. Rubber dam use during root canal treatment: findings from The Dental PracticeBased Research Network. J. Am. Dent. Assoc., 144(2):179-86, 2013.

Anderson, A. C.; Andisha, H.; Hellwig, E.; Jonas, D.; Vach, K. \& AlAhmad, A. Antibiotic resistance genes and antibiotic susceptibility of oral Enterococcus faecalis isolates compared to isolates from hospitalized patients and food. Adv. Exp. Med. Biol., 1057:4762, 2018.

Barbosa-Ribeiro, M.; De-Jesus-Soares, A.; Zaia, A. A.; Ferraz, C. C.; Almeida, J. F. \& Gomes, B. P. Antimicrobial susceptibility and characterization of virulence genes of Enterococcus faecalis isolates from teeth with failure of the endodontic treatment. J. Endod., 42(7):1022-8, 2016.

Bolfoni, M. R.; Pappen, F. G.; Pereira-Cenci, T. \& Jacinto, R. C. Antibiotic prescription for endodontic infections: a survey of Brazilian endodontists. Int. Endod. J., 51(2):148-56, 2018.

Chouchani, C.; El Salabi, A.; Marrakchi, R.; Ferchichi, L. \& Walsh, T. R. First report of mefA and $\mathrm{msr} A / \mathrm{msrB}$ multidrug efflux pumps associated with blaTEM-1 b-lactamase in Enterococcus faecalis. Int. J. Infect. Dis., 16(2):e104-9, 2012.

Davies, J. \& Davies, D. Origins and evolution of antibiotic resistance. Microbiol. Mol. Biol. Rev., 74(3):417-33, 2010.

Davis, D. R.; McAlpine, J. B.; Pazoles, C. J.; Talbot, M. K.; Alder, E. A.; White, C.; Jonas, B. M.; Murray, B. E.; Weinstock, G. M. \& Rogers, B. L. Enterococcus faecalis multi-drug resistance transporters: application for antibiotic discovery. J. Mol. Microbiol. Biotechnol., 3(2):179-84, 2001.

Duggan, J. M. \& Sedgley, C. M. Biofilm formation of oral and endodontic Enterococcus faecalis. J. Endod., 33(7):815-8, 2007.

Fontana, R.; Amalfitano, G.; Rossi, L. \& Satta, G. Mechanisms of resistance to growth inhibition and killing by beta-lactam antibiotics in enterococci. Clin. Infect. Dis., 15(3):486-9, 1992.

Fosse, T.; Madinier, I.; Hannoun, L.; Giraud-Morin, C.; Hitzig, C.; Charbit, Y. \& Ourang, S. High prevalence of cfxA beta-lactamase in aminopenicillin-resistant Prevotella strains isolated from periodontal pockets. Oral Microbiol. Immunol., 17(2):85-8, 2002.
Goldfein, J.; Speirs, C.; Finkelman, M. \& Amato, R. Rubber dam use during post placement influences the success of root canaltreated teeth. J. Endod., 39(12):1481-4, 2013.

Gomes, B. P.; Jacinto, R. C.; Montagner, F.; Sousa, E. L. \& Ferraz, C. C. Analysis of the antimicrobial susceptibility of anaerobic bacteria isolated from endodontic infections in Brazil during a period of nine years. J. Endod., 37(8):1058-62, 2011.

Jain, H.; Mulay, S. \& Mullany, P. Persistence of endodontic infection and Enterococcus faecalis: Role of horizontal gene transfer. Gene Rep., 5:112-6, 2016.

Jungermann, G. B.; Burns, K.; Nandakumar, R.; Tolba, M.; Venezia, R. A. \& Fouad, A. F. Antibiotic resistance in primary and persistent endodontic infections. J. Endod., 37(10):1337-44, 2011.

Komiyama, E. Y.; Lepesqueur, L. S.; Yassuda, C. G.; Samaranayake, L. P.; Parahitiyawa, N. B.; Balducci, I. \& Koga-Ito, C. Y. Enterococcus species in the oral cavity: prevalence, virulence factors and antimicrobial susceptibility. PLoS One, 11(9):e0163001, 2016.

Koukos, G.; Konstantinidis, A.; Tsalikis, L.; Arsenakis, M.; Slini, T. \& Sakellari, D. Prevalence of b-lactam (bla TEM) and Metronidazole (nim) Resistance Genes in the Oral Cavity of Greek Subjects. Open Dent. J., 10:89-98, 2016.

Kuroda, M.; Sekizuka, T.; Matsui, H.; Suzuki, K.; Seki, H.; Saito, M. \& Hanaki, H. Complete genome sequence and characterization of linezolid-resistant Enterococcus faecalis Clinical isolate KUB3006 carrying a cfr(B)-transposon on its chromosome and optrA-plasmid. Front. Microbiol., 9:2576, 2018.

Lins, R. X.; de Oliveira Andrade, A.; Hirata Junior, R.; Wilson, M. J.; Lewis, M. A.; Williams, D. W. \& Fidel, R. A. Antimicrobial resistance and virulence traits of Enterococcus faecalis from primary endodontic infections. J. Dent., 41(9):779-86, 2013.

Lopardo, H. \& Blanco, A. Métodos para detectar enterococos productores de b-lactamasa. Rev. Argent. Reumatol., 45(2):86-8, 2007.

Medeiros, A. W.; Pereira, R. I.; Oliveira, D. V; Martins, P. D.; D'Azevedo, P. A.; Van der Sand, S.; Frazzon, J. \& Frazzon, A. P. G. Molecular detection of virulence factors among food and clinical Enterococcus faecalis strains in South Brazil. Braz. J. Microbiol., 45(1):327-32, 2014.

Miller, W. R.; Munita, J. M. \& Arias, C. A. Mechanisms of antibiotic resistance in enterococci. Rev. Ant. Infect. Ther., 12(10):122136, 2014.

Min, Y. H.; Kwon, A. R.; Yoon, J. M.; Yoon, E. J.; Shim, M. J. \& Choi, E. C. Molecular analysis of constitutive mutations in ermB and ermA selected in vitro from inducibly MLSB-resistant enterococci. Arch. Pharm. Res., 31(3):377-80, 2008.

Nair, P. N. R. Pathogenesis of apical periodontitis and the causes of endodontic failures. Crit. Rev. Oral Biol. Med., 15(6):348-81, 2004.

$\mathrm{Ng}$, L. K.; Martin, I.; Alfa, M. \& Mulvey, M. Multiplex PCR for the detection of tetracycline resistant genes. Mol. Cell. Probes, 15(4):209-15, 2001.

Oberoi, S. S.; Dhingra, C.; Sharma, G. \& Sardana, D. Antibiotics in dental practice: How justified are we. Int. Dent. J., 65(1):4-10, 2015.

Pereira, L. A.; Harnett, G. B.; Hodge, M. M.; Cattell, J. A. \& Speers, D. J. Real-time PCR assay for detection of blaZ genes in Staphylococcus aureus clinical isolates. J. Clin. Microbiol., 52(4):1259-61, 2014.

Pinheiro, E. T.; Gomes, B. P. F. A.; Ferraz, C. C. R.; Teixeira, F. B.; Zaia, A. A. \& Souza Filho, F. J. Evaluation of root canal microorganisms isolated from teeth with endodontic failure and their antimicrobial susceptibility. Oral Microbiol. Immunol., 18(2):100-3, 2003.

Pitkälä, A.; Salmikivi, L.; Bredbacka, P.; Myllyniemi, A. L. \& Koskinen, M. T. Comparison of Tests for Detection of-Lactamase-Producing Staphylococci. J. Clin. Microbiol., 45(6):2031-3, 2007. 
Poveda Roda, R.; Bagán, J. V.; Sanchis Bielsa, J. M. \& Carbonell Pastor, E. Antibiotic use in dental practice. A review. Med. Oral Patol. Oral Cir. Bucal, 12:186-92, 2007.

Prazmo, E.; Godlewska, R.; Kwasny, M. \& Mielczarek, A. Virulence factors of Enterococcus faecalis in relation to pulp diseases and periapical infections. Postep. Mikrobiol., 55:247-54, 2016.

Preethee, T.; Kandaswamy, D. \& Hannah, R. Molecular identification of an Enterococcus faecalis endocarditis antigen efaA in root canals of therapy-resistant endodontic infections. J. Conserv. Dent., 15(4):319, 2012.

Rams, T. E.; Feik, D.; Mortensen, J. E.; Degener, J. E. \& van Winkelhoff, A. J. Antibiotic susceptibility of periodontal Enterococcus faecalis. J. Periodontol., 84(7):1026-33, 2013.

Roberts, A. P.; Davis, I. J.; Seville, L.; Villedieu, A. \& Mullany, P. Characterization of the ends and target site of a novel tetracycline resistance-encoding conjugative transposon from Enterococcus faecium 664.1H1. J. Bacteriol., 188(12):4356-61, 2006.

Rôças, I. N. \& Siqueira, J. F. Antibiotic resistance genes in anaerobic bacteria isolated from primary dental root canal infections. Anaerobe, 18(6):576-80, 2012.

Rôças, I. N. \& Siqueira, J. F. Detection of antibiotic resistance genes in samples from acute and chronic endodontic infections and after treatment. Arch. Oral Biol., 58(9):1123-8, 2013.

Rodriguez-Núñez, A.; Cisneros-Cabello, R.; Velasco-Ortega, E.; Llamas-Carreras, J. M.; Tórres-Lagares, D. \& Segura-Egea, J. J. Antibiotic use by members of the Spanish Endodontic Society. J. Endod., 35(9):1198-203, 2009.

Sánchez-Sanhueza, G.; González-Rocha, G.; Dominguez, M. \& Bello-Toledo, H. Enterococcus spp. isolated from root canals with persistent chronic apical periodontitis in a Chilean population. Braz. J. Oral Sci., 14(3):240-5, 2015.

Sánchez-Sanhueza, G.; Villegas, C.; Ma, ; Ulloa, I.; Pineda, C.; González-Rocha, G.; Domínguez, M. \& Bello-Toledo, H. Molecular typing of Enterococcus faecalis from persistent endodontic infections. Int. J. Odontostomat., 12(1):113-9, 2018.

Segura-Egea, J. J.; Gould K.; S,en, B. H.; Jonasson, P.; Cotti, E.; Mazzoni, A.; Sunay, H.; Tjäderhane, L. \& Dummer, P. M. H. European Society of Endodontology position statement: the use of antibiotics in endodontics. Int. Endod. J., 51(1):20-5, 2018.

Skucaite, N.; Peciuliene, V.; Vitkauskiene, A. \& MacHiulskiene, V. Susceptibility of endodontic pathogens to antibiotics in patients with symptomatic apical periodontitis. J. Endod., 36(10):1611-6, 2010.

Stuart, C. H.; Schwartz, S. A.; Beeson, T. J. \& Owatz, C. B. Enterococcus faecalis: Its role in root canal treatment failure and current concepts in retreatment. J. Endod., 32(2):93-8, 2006.

Sukumar, S.; Roberts, A. P.; Martin, F. E. \& Adler, C. J. Metagenomic insights into transferable antibiotic resistance in oral bacteria. $J$. Dent. Res., 95(9):969-76, 2016.

Sun, J \& Song, X. Assessment of antimicrobial susceptibility of Enterococcus faecalis isolated from chronic periodontitis in biofilm versus planktonic phase. J. Periodontol., 82(4):626-31, 2011.

Sun, J.; Sundsfjord, A. \& Song, X. Enterococcus faecalis from patients with chronic periodontitis: virulence and antimicrobial resistance traits and determinants. Eur. J. Clin. Microbiol. Infect. Dis., 31(3):267-72, 2012

Troncoso, C.; Pavez, M.; Santos, A.; Salazar, R. \& Barrientos, L. Structural and physiological implications of bacterial cell in antibiotic resistance mechanisms. Int. J. Morphol., 35(4):121423, 2017.

Vergis, J.; Pathak, R.; Kumar, M.; Sunitha, R.; Malik, S. V. S.; Barbuddhe, S. B. \& Rawool, D. B. A comparative study for detection of extended spectrum b-lactamase (ESBL) production by Enteroaggregative Escherichia coli (EAEC) strains using double disc, nitrocefin and PCR assays. J. Microbiol. Methods, 151:57-61, 2018.
Wade, W. G. Has the use of molecular methods for the characterization of the human oral microbiome changed our understanding of the role of bacteria in the pathogenesis of periodontal disease? J. Clin. Periodontol., 38:7-16, 2011.

Yin, M.; Jiang, Y.; Qian, C.; Wu, F.; Ying, Y.; Wu, C.; Li, P.; Ying, J.; Li, K.; Xu, T.; Bao, Q. \& Sun, C. Molecular characteristics and comparative genomics analysis of a clinical Enterococcus casseliflavus with a resistance plasmid. Infect. Drug Resist., 11:2159-67, 2018

Zhu, X.; Wang, Q.; Zhang, C.; Cheung, G. S. P.; \& Shen, Y. Prevalence, phenotype, and genotype of Enterococcus faecalis isolated from saliva and root canals in patients with persistent apical periodontitis. J. Endod., 36(12):1950-5, 2010.

Corresponding author:

Gabriela Sánchez-Sanhueza DDS, MEd, PhD.

Departamento de Odontología Restauradora

Facultad de Odontología

Universidad de Concepción

Concepción

CHILE

Email: gasanchez@udec.cl

Received: 16-01-2020

Accepted: 26-02-2020 